\title{
Time Provisions in Standard Forms of Local and International Construction Contract
}

\author{
Ling Zhe Huei ${ }^{1}$, Ting Sim Nee ${ }^{2}$
}

\begin{abstract}
In any construction contract, the use terms and conditions in construction contract clauses has a great impact on the project performance, which in turn affects the achievement of the project completion date. Clauses within a contract should fit together to form a reasonably allocated risk among project parties and relevant to the complexity of projects. The General Condition clauses, which were looked at in this study, consist of the ones that relate to the time performance of the contract as well as that deal with action required at specific points in time within a contract. As we know, a clear and more complete General Condition documentation should end up with win-win situations for parties involved. If there are much unclear and even unknown information within the General Condition, the parties contracting will encounter uncertainties with relations to time that during the project execution. For the parties contracting, it is always to their advantage if more complete and comprehensive documentation used as it means fewer disputes, less conflicts, and time and energy saving during construction instead of claiming and debating over the provisions. The paper is to present an analysis on the time related clauses and provisions in the current local (used in Malaysia) and international construction contracts.
\end{abstract}

Keywords: standard form, time provisions, construction contracts

\section{INTRODUCTION}

A civil engineering construction contract is one in which the contractor's principal obligation is to carry out works of civil engineering construction [3]. The contract may also oblige the contractor to carry out ancillary obligation such as maintenance or operation of the works. Civil engineering contracts are generally made, interpreted and enforced in the same way as any other commercial contract [2].

As mentioned by Williams [11], in order to produce a legally binding contract, all contracts must meet certain primary ingredients. Firstly, there must have a meeting of the minds between parties regarding the purpose of the contracts. If the meeting of the mind is achieved by the elements of 'offer' and 'acceptance', the contract will be created. Then, both parties in a contract must contribute something of value to the bargain to demonstrate good faith, and this contribution is known as consideration.

Besides, according to Robinsons and Lavers [9], standard form of construction contracts provides a basic legal framework identifying the rights, obligations and duties of the parties. It also established the ambit of the powers and duties of the contract administrator as well as put in place the administrative procedures necessary for operation of the contract. There are appreciable savings in time and costs when standard forms, which are the general conditions of the contract, are used compared to the costs of drawing up fresh contracts.

The Standard Form of Construction Contracts commonly used in Malaysia includes the Agreement and Conditions of PAM Contract (with Quantities), the PAM1998 and 2006 Forms issued under the sanction of the Pertubuhan Arkitek Malaysia, JKR or PWD Forms issued by the Public Works Department of Malaysia, CIDB Standard Form of Contract for Building Works 2000 (CIDB 2000) issued by the Construction Industry Development Board, IEM forms issued by the Institute of Engineers of Malaysia, FIDIC forms issued by the Federation Internationale des Ingenieurs-Conseils and other minor forms drafted by individual organisations to be used for their own projects

Most countries in the world have their own standard forms of general conditions to be used in their respective construction industry. The standard forms for different countries are set according to the conditions and situations in their respective countries. For instance, Australian Standard (AS) Forms are the most common standard forms used in Australia; the 
American uses the AIA Documents extensively in the building contracts; and ICE Conditions of Contract (ICE forms), the New Engineering Contract Engineering and Construction contracts (NEC ECC forms) and Joint Contract Tribunal family of forms (JCT Forms) are well used within the British construction industry.

\subsection{Time in Construction}

As been mentioned by Hinze [4], time requirement plays a key role to both employer and contractor in any construction contract. And time has always been said to be as important as cost. It is always in the best interest of the owner and contractor to have the work completed within the scheduled time and budget. Hence, the provision of time aspect in every construction contracts has been an important aspect and is to be treated with care by all contracting parties in order to avoid any time related problems and/or disputes.

Contract documents and in particular the standard form of General Conditions would normally contain various clauses that are related to the matters of time. Time clauses in standard forms generally include working days, completion date, limitation of operations, liquated damages, extension of time, excusable delays, acceleration of work, suspension of works, termination, and project completion.

\section{OVERVIEW OF TIME RELATED CLAUSES}

In the quest of producing the better forms and conditions of contract, there is a need to incorporate the views of the different interested groups within the construction industry, such as employers, designers and contractors. Hence, comparison of time related clauses and provisions of different Standard Form of Contract are reviewed according to the effects they have when used by our construction industry [4].

According to Ashley and Workman [1], a literature search revealed that the subject of examining the standard form of contract time related clauses has not been extensively studied. Much has been written on the subject of contract types, scheduling methods and techniques, and cost and risk management. In fact, very few researches have been conducted studies on how contract clauses affecting time can impact contract administration.

Among Malaysian standard form of contracts, only PAM 1998 Form and CIDB 2000 had stated the requirement of preparing work programme while PWD 203A does not include this matter. It is stated under Clause 3.4 of PAM 1998 Form and also in CIDB 2000 under clause 5.1. However, the work programme requirements are debarred by clause 3.5 of the PAM 1998 Form and clause 5.2 of the CIDB 2000 respectively from having any formal significance over contractual obligations. The contractor who fails to produce an effective and realistic programme puts himself at a disadvantage on proof of entitlement to extension of time.

Besides, according to Williams [11], the old Clause 14(1) in the $5^{\text {th }}$ edition of ICE Conditions of Contract is rewritten to include the requirement that in the event of his 'Clause 14' programme being rejected, the Contractor must submit a revised programme within 21 days of the rejection. Clause 14(2) is a new sub-clause in the $6^{\text {th }}$ Edition of ICE Conditions of Contract which requires the Engineer to respond within 21 days to the Contractor's submission of his programme, failing which such programme will be deemed to have been accepted. Clause 14(3) is also a new sub- clause requiring the Contractor to respond within 21 days to a request by the Engineer to supply further information relating to the above programme. Failing a time respond, the programme will be deemed to have been rejected.

Extension of time is another important time provision in the construction contract. Clause 23.0 of the PAM 1998 Form, which deals with extension of time, has some improvements made to in comparison with the PAM/ISM 1969 Form. Rajoo [8] mentioned that unlike the limited provision of Clause 23 of the PAM/ISM 1969 Form, Clause 23.1 of the PAM 1998 Form expands the obligation of the contractor to notify the architect of events causing delay. Compared to Clause 23 of the PAM/ISM 1969 Form, Clause 23.7 of the PAM 1998 Form sets out a list of twelve (12) relevant events causing delay instead of ten (10), which includes additional grounds that the occurrence of which may trigger off a claim for an extension of time [8].

Furthermore, Clause 44 in the $5^{\text {th }}$ Edition and $6^{\text {th }}$ Edition of ICE Conditions of Contract discusses about extension of time for completion. According to Williams [11], this clause in $6^{\text {th }}$ edition is substantially the same as its predecessor except that it now contains five (5) sub-clauses instead of four (4). A notable addition thereto is the requirement that the Engineer, prior to making his interim assessment of the appropriate extension of time, makes an initial assessment of any delay claimed by the Contractor and notify the latter accordingly. Whereas the previous version of the clause required the Engineer to update his assessment of any extension to the contract completion time 'on or as soon as possible after the due date for completion'. Clause $44(4)$ in the $6^{\text {th }}$ Edition requires that such be made 'within 14 days' after the said date. Furthermore, Clause 44(5) in the $6^{\text {th }}$ Edition requires certification of the overall extension of completion time 'within 14 days' after the issue of the completion Certificate and not, as previously required in $5^{\text {th }}$ edition, 'upon' such issue.

According to Mort [6], Clause 61.3 in the $2^{\text {nd }}$ Edition of ECC provides that the contractor is to notify the project manager of the occurrence of a compensation event "if it is less than two weeks since he became aware of the event". It is left to the 
reader to infer that notification of a compensation event by the contractor after 2 weeks as ineffective. Besides that, with the absence of timely notification, the contractor would not be entitled to pursue the remainder of the compensation event procedure or otherwise recover additional payment and/or modification to the completion date. Hence, it is not clear that such inferences could properly be drawn. Whilst Clause 61.3 in the 3rd Edition of ECC provides "If the contractor does not notify a compensation event within eight weeks of becoming aware of the event, he is not entitled to a change in the prices, the completion date or a key date unless the project manager should have notified the event to the contractor but did not." Besides, the terms of new clause 63.4 of 3rd edition of ECC should also be noted in this context: "The rights of the employer and the contractor to changes to the prices, the completion date and the key dates are their only rights in respect of a compensation event." The new wording of Clause 61.3, besides providing for a lengthier notification period, is perhaps clearer in identifying the general intent. A contractor may therefore feel obliged to notify the project manager of all compensation events in order to protect its position.

According to Pilley and Combes[7], important improvements have been made in relation to the extension of time clause, making it clear that the contractor must continually apply for specified extensions of time, overcoming a deficiency which currently exists in AS2124-1992, where the contractor is not obliged to apply for a specific extension of time until such time as the period of extension required has become known. It also overcomes problems of the principal being in breach of the contract if the superintendent fails within 28 days to assess an extension of time application made by the contractor.

Rajoo[8] mentioned that Clause 21.0 deals with dates of commencement, dates of commencement given for sections, postponement and date for completion. This clause in the PAM 1998 Form has been rewritten and substantially extended to contain four (4) sub-clauses instead of two (2) in the PAM/ISM 1969 Form. Besides, the new sub-clauses (Clause 21.2 and 21.3) go on to improve the inadequacy of the PAM/ISM 1969 Form in dealing with commencement and completion in phases or sections. This is because the employer's failure to give possession of the site is not covered by the provision of Clause 21.2 of the PAM/ISM 1969 Form, which merely entitles the architect/superintendent of the job to postpone 'any work to be executed under the provisions of the Contract'.

\section{PROBLEM STATEMENT}

From this overview on the comparison different construction standard forms, it is found that time related clauses and provisions differ from one Standard Form of Construction Contract to another. By reviewing on the existing comments on various time clauses in standard forms of construction contracts by some researchers, it was found that there are problems that are caused by ineffective time related clauses and provisions. The following includes some examples on less than adequate provision that makes less than effective time related clauses.

Firstly, time provision in standard form of contract may or may not state that the requirements for submission of work program. In Malaysian standard form of contract, only PAM 1998 Form and CIDB 2000 stated the requirement of preparing work programme in document contracts whereas PWD 203A form fails to state the requirements. Idris [5] stated that the contractor's failure to submit the work programme may reduce the number of expressed provisions operating in favour of him when delays occur.

Besides, notification of compensation event is an important clause under time provision to recover additional payment or modification to time for completion. Looking into clause 61.3 of the $2^{\text {nd }}$ Edition of ECC, it provides that the contractor was to notify the project manager of the occurrence of a compensation event after two weeks [6]. Notification of a compensation event by the contractor after two weeks is consider as ineffective. Problem will arise when that the contractor would not be entitled to pursue the notification of compensation event procedure to recover additional payment and make any performance modification to the completion date due to the absence of timely notification.

Other than that, extension of time is also one of the important time provisions, which extends the time of completion. Looking into extension of time clause of AS2124-1992, it is stated that the contractor is not obliged to apply for a specific extension of time until such time as the period of extension required has become known. Problems arise when the contractor is found not applying and hence, not fulfilling his obligations because the superintendent fails within 28 days to assess a previous extension of time application made by the contractor. This may result in the contractor unable to complete the project within a reasonable time frame.

From the above, it is found that time related clauses and provisions in different construction standard forms of contract do differ from each other. These differentiations have brought about effect contracting parties performing their contractual obligations. Contracting parties who are familiar with one forms may face difficulties in understanding and thus, executing their obligations effectively when they are presented with another forms. The contractor especially as the major party in executing their obligations on the construction site, often are left to deal with consequences of different and or ambiguous time related clauses and provisions.

It is reasonable to summarise that certain ineffective time clauses and provisions in standard form of construction contract may prevent affect the performance of the contractor of a set of contract. The contractor may face difficulties in achieving project time target especially when their contractual obligations are ambiguous under the time related clauses and provisions 
in the standard forms of construction contracts. Therefore, it is necessary to study in depth certain time related clauses and provisions in different of standard forms of construction contracts that affect the performance of contractors. It is important to understand some of the more frequently used standard forms that are used in Malaysia. A point of reference will be made with an overseas standard form.

\section{METHODOLOGY}

In this research study, Agreement and Conditions of PAM 2006 Contract 2006 (With Quantities) and Australian Standard General Conditions of Contract (AS2124- 1992) are being chosen to be used as points of reference in making comparison with JKR Sarawak Form of Contract Revision 2006, PWD 75 (Rev.2006). Analysis and comparison on the standard form of construction contract will first be carried out. Comparison would be made based on the eight (8) major sections that PWD 75 (Rev.2006) can be categorised in. These eight (8) major sections are days and working days, possession of site, commencement of work, work of programme, delay and extension of time, suspension, acceleration and completion.

The eight (8) sections would be compared with respect to the completeness. Completeness is defined as whether time clauses and provisions cover all the basic and necessary contractual aspects of time. Another parameter of comparison is with respect to clarity. The lack of clarity in the contract would give rise to misinterpretation difficulty in understanding the terms used for the standard form of construction contract. This is because the interpretations of contract clauses are usually not attached within contract. Then, the results obtained from the analysis and comparison will be discussed by further qualitative analysis from semi-structured interview of (6) six construction contract related persons and a case study conducted. From the result obtained, it is hopeful that a better understanding on adequate of time related clauses and provisions can be achieved and what is offer in various local and international standard forms of construction contracts can be better known. Any recommendations made will be in view of helping the contractor's performance in carrying out their contractual obligations and better and more effective administration of the contract.

\section{RESEARCH ANALYSIS}

\subsection{Results from forms analysis}

As mentioned above, the analysis is conducted for (3) three standard forms of construction contracts that is the PWD 75 (Rev.2006), PAM Contract 2006, AS2124-1992. The reader should refer the table 1 that summarizes the findings.

Table 1: Research finding for time related clauses and provisions

\begin{tabular}{|c|c|c|c|c|c|}
\hline No. & Time provision & $\begin{array}{l}\text { PWD } 75 \\
\text { (Rev.2006) }\end{array}$ & $\begin{array}{l}\text { PAM Contract } \\
2006\end{array}$ & AS2124-1992 & Finding and recommendation \\
\hline 1 & $\begin{array}{l}\text { Working days and } \\
\text { hours }\end{array}$ & $\begin{array}{l}\text { Complete } \\
\text { Clear } \\
\text { Effective }\end{array}$ & $\begin{array}{l}\text { Incomplete } \\
\text { Unclear } \\
\text { Ineffective }\end{array}$ & $\begin{array}{l}\text { Complete } \\
\text { Clear } \\
\text { Effective }\end{array}$ & $\begin{array}{l}\text { Time frame for days and hours is to } \\
\text { inform the Contractor on when they can } \\
\text { do their works } \\
\text { Standard form must provide time } \\
\text { provision to allow contractor to work } \\
\text { outside time frame. }\end{array}$ \\
\hline 2 & Possession of site & $\begin{array}{l}\text { Complete } \\
\text { Clear } \\
\text { Effective }\end{array}$ & $\begin{array}{l}\text { Incomplete } \\
\text { Unclear } \\
\text { Ineffective }\end{array}$ & $\begin{array}{l}\text { Incomplete } \\
\text { Clear } \\
\text { Ineffective }\end{array}$ & $\begin{array}{l}\text { Specified date of "Date of Possession of } \\
\text { Site" } \\
\text { Clearly state the definition of the partial } \\
\text { site to avoid any arising problem. } \\
\text { Date stated for possession of site could be } \\
\text { earlier than the date of commencement of } \\
\text { work }\end{array}$ \\
\hline 3 & $\begin{array}{l}\text { Commencement of } \\
\text { work }\end{array}$ & $\begin{array}{l}\text { Incomplete } \\
\text { Clear } \\
\text { Ineffective }\end{array}$ & $\begin{array}{l}\text { Incomplete } \\
\text { Unclear } \\
\text { Ineffective }\end{array}$ & $\begin{array}{l}\text { Incomplete } \\
\text { Clear } \\
\text { Ineffective }\end{array}$ & $\begin{array}{l}\text { Commencement dates are stated in each } \\
\text { form } \\
\text { Confusing meaning of "regularly and } \\
\text { diligently" is recommended to modify } \\
\text { Time provision of "Dates of } \\
\text { Commencement given for sections" is } \\
\text { recommended to be put into the PWD } 75 \\
\text { (Rev.2006) }\end{array}$ \\
\hline 4 & Work programme & $\begin{array}{l}\text { Incomplete } \\
\text { Clear } \\
\text { Ineffective }\end{array}$ & $\begin{array}{l}\text { Incomplete } \\
\text { Clear } \\
\text { Ineffective }\end{array}$ & $\begin{array}{l}\text { Complete } \\
\text { Clear } \\
\text { Effective }\end{array}$ & $\begin{array}{l}\text { Criteria of form of work programme is } \\
\text { recommended to add into PWD } 75 \\
\text { (Rev.2006) }\end{array}$ \\
\hline 5 & Delay and & Incomplete & Complete & Incomplete & Contractors to follow prescribed contract \\
\hline
\end{tabular}




\begin{tabular}{|l|l|l|l|l|l|}
\hline & extension of time. & $\begin{array}{l}\text { Unclear } \\
\text { Ineffective } \\
\text { Effective }\end{array}$ & $\begin{array}{l}\text { Clear } \\
\text { Ineffective }\end{array}$ & $\begin{array}{l}\text { procedures and prove entitlement to be } \\
\text { granted time extension. } \\
\text { More relevant delay cause event is } \\
\text { recommended to add into PWD 75 } \\
\text { (Rev.2006). } \\
\text { Reviewing the decision on granted } \\
\text { extension of time and claiming of } \\
\text { extension of time are recommended. }\end{array}$ \\
\hline 6 & Suspension & $\begin{array}{l}\text { Incomplete } \\
\text { Unclear } \\
\text { Ineffective }\end{array}$ & $\begin{array}{l}\text { Incomplete } \\
\text { Unclear } \\
\text { Ineffective }\end{array}$ & $\begin{array}{l}\text { Complete } \\
\text { Clear } \\
\text { Effective }\end{array}$ & $\begin{array}{l}\text { New provision is recommended to PWD } \\
75 \text { (Rev.2006). } \\
\text { Subject it as the relevant cause for } \\
\text { claiming extension of time. }\end{array}$ \\
\hline 7 & Acceleration & $\begin{array}{l}\text { Incomplete } \\
\text { Unclear } \\
\text { Ineffective }\end{array}$ & $\begin{array}{l}\text { Incomplete } \\
\text { Unclear } \\
\text { Ineffective }\end{array}$ & $\begin{array}{l}\text { Complete } \\
\text { Clear } \\
\text { Effective }\end{array}$ & $\begin{array}{l}\text { New provision is recommended to PWD } \\
75 \text { (Rev.2006). } \\
\text { It is recommended that providing a power } \\
\text { for acceleration to be ordered in the event } \\
\text { of the contractor's default in progressing } \\
\text { with due diligence, without additional } \\
\text { payment. }\end{array}$ \\
\hline 8 & Completion of work & $\begin{array}{l}\text { Complete } \\
\text { Clear } \\
\text { Effective }\end{array}$ & $\begin{array}{l}\text { Complete } \\
\text { Clear } \\
\text { Effective }\end{array}$ & $\begin{array}{l}\text { Incomplete } \\
\text { Unclear } \\
\text { Ineffective }\end{array}$ & $\begin{array}{l}\text { Give interpretations of the "Date for } \\
\text { Practical Completion", "Date of Practical } \\
\text { Completion" } \\
\text { Completions". }\end{array}$ \\
\hline
\end{tabular}

\subsection{Discussion}

a) Working days and hours

A working day is any day in a week except Saturdays, Sundays, and public holidays, where the contractor performs work or could have performed work. The contractor cannot execute their work randomly in any days and hours. According to the interviewee/s, there should be a definition time frame for days and time of work. The contractor is allowed to work outside the time frame if there is no express term in the contract. According to the same interviewee, if the contractor carries out the work outside normal working hours without the permission of the Superintending Officer, the contractor himself should take the risk against the work and is responsible for any problems that may occur

\section{b) Possession of site}

The owner should give the contractor sufficient access to or possession of the site to allow meeting of his or her obligations and meet the deadlines specified in the contract. This helps the contractor in having realistic planning for the work and manpower loading throughout the period of construction. When it is not the contractor's responsibility, any delay in the possession of site may entitle the contractor to an extension of time and agreed compensation for delay [1]. It is seen that this time provision is very important. In the case of London Borough of Merton v Stanley High Leach (1985) 32 BLR 51, in Merton, terms require that the building owner shall give possession of the site within reasonable time, and give instructions and information at reasonable times. In Canadian case of Penvidic Contracting Co. Ltd v. International Nickel Co. of Canada Ltd [1975] 53 DLR 748, a new project term would normally be expressed that the site would be handed over within a reasonable time and with a sufficient uninterrupted possession to allow the Contractor to carry out their obligations.

\section{c) Commencement of work}

The Contractor starts carry out works under the contract within the specified contract period after receiving the site. It is necessary to have notification to the owner by Contractor before commence of work. The interviewee/s stated that the owner needs to have a reasonable amount of time before the actual commencement of work on the site to record mortgages and other security interests. Besides, interpretation of "regularly and diligently" is confusing when used to explain the obligation of contractor when executing and finishing their works on time. In the case West Faulkner v London Borough of Newham (1994) 71 BLR 1, the Court of Appeal acknowledged the difficulty of defining "diligently" when the proper construction of the term regularly and diligently was considered.

\section{d) Work programme}

In order to enable the engineer to satisfy himself that the contractor is able to discharge his contractual obligations within the specified completion, it is important to submit a construction programme work to engineer under time provision in standard form of contract after awarding the construction contract and usually before the Pre-construction conference [11]. Work programme play an important role for contractor to execute work and this is supported by the interviewee/s that works programme is an important document for applying extension of time. Besides, submission of method statement is important 
for contractor when carrying their works. In case English Industrial Estates Corporation v Kier Construction Ltd [1991] 56 BLR 93, the contractor can deal with variation if the specified method is required to be changed.

e) Delay and extension of time

Contractor will be required to pay liquidated damages or any monetary compensation to the employer if he delays the project completion without a valid reason [10]. Besides, contractor will not be entitled to claim extra money or time if the delay is due to defaults of his own doings. Most of the standard form of construction contract provides provision of condition precedent and it is very important for contractor. In the case Gaymark Investments v Walter Construction Nothern Territory Supreme Court 143 [1999], the Architect had no discretion to award an extension of time in the absence of the contractor's application in accordance with the condition precedent. It is found that notification of the extension of time is short in period in PWD 75 (Rev.2006). It is commented by the interviewee/s that the contractor is unable to make it in a lot of cases in the real construction industry. Besides should there be additional current, individual project related and reasonable events causing delay included in the contract, it will assist the contractor in claiming their extension of time. According to interviewee, the contractor will only be granted extension of time if the cause of delay listed in the contract.

\section{f) Suspension}

Suspensions may result from an action of the contractor or the owner. The most important components of these provisions are related to the general nature of suspensions and the ability of the contractor to re-cover costs associated with owner suspensions. Contract contingencies will occur if the suspension provisions stated in the contract do not permit the contractor to recover damages caused by an owner's suspension or project delay. The contractor's recovery of damages is typically restricted to instances where the contractor is not at fault [4]. Lack of provision of suspension must be avoided. It is supported by the interviewee/s that the issue of suspension often arises where a contractor wishes to suspend work due to the employer's failure to make progress payments, or for some other serious but remediable breach of contract. It is necessary to provide certain provisions that allow the contractor to suspend the work, whenever deemed reasonably necessary.

\section{g) Acceleration}

The contractor should make a request for time extension if he falls behind schedule on a project due to unforeseen delays beyond his or her own control. If the owner denied the time extension request and asked the contractor to complete the project and abide with the original date stipulated in the contract, the contractor should abide and must proceed with the contract work under progress. Lack of provision of acceleration of work either actual or constructive acceleration will affect the performance of contractor when carrying their contractual obligations. According to the interviewee/s, the main problem faced by the contractor is that in the absence of an extension of time the contractor may be faced with the possibility of liquidation damages being levied against him. If the owner enforces the original completion date, the contractor can consider this as a constructive acceleration. In Motherwell Bridge Construction Ltd (t/a Motherwell Storage Tanks) v Micafil Vakuumtechnick [2002] 81 Con LR 44, Motherwell was entitled to claim the costs of acceleration and premium time incurred in attempting to avoid the imposition of liquidated damages

\section{h) Completion of work}

Most of the standard forms of construction contracts do not contain expressed term for extent of the work progress. In case GLC v Cleveland Bridge and Engineering Co Ltd [1984] and Pigott Foundations Ltd v Shepherd Construction Ltd [1993] it is proven that in the absence of any indication to the contrary, the contractor has absolute discretion as to how the work is planned and performed, provided only that it is completed on time. Interpretation of the "Completion", "Substantial Completion" and "Practical Completion" is important to avoid any misunderstanding of the contractor to decide which extent of completion had been achieved it is supported by Emson eastern Ltd v EME Developments Ltd [1991] 55 BLD 114. Judge John Newey QC has the view that a building can seldom be built precisely as required by the drawings and specifications.

\section{CONCLUSION AND RECOMMENDATION}

The main conclusions ascertained in this research are as follow:

a. Each standard form of construction contract used in Malaysia consists of effective and ineffective time clause.

b. Standard forms of construction contract with ineffective time clauses will affect the performance of contractor when carrying out their contractual obligations.

c. Time provision in PWD 75 (Rev.2006) has included most of the necessary time-related provision but the form is still in need of improvement or modifications in order to user friendly in the construction industry.

d. Some of the time provision in AS2124-1992 like acceleration and suspension can be introduced into the PWD 75 (Rev.200). 
Overall, the time provisions in PWD 75 (Rev.2006) are considered as adequate but still in need of modification to suit today's construction industry. The clauses are either incomplete or requires additional clause to support and provided more explanations to improve on the clarity and completeness aspects. The time provision of working days and hours is complete, clear suitable for use for Contractor in the construction industry without any problems. Possession of site, commencement of work, work programme, delay and extension of time, completion of work are requires the additional clauses and more explanations. Besides, suspension and acceleration are the new provision that recommended to be added into the PWD 75 (Rev.2006). Any incompleteness and ambiguity with time related clauses and provisions in PWD 75 (Rev.2006) is proved to be able to influence the performance of the Contractor in terms of their obligations. It is shown that the standard forms of construction contracts with ineffective time clauses will affect the performance of contractor.

In addition, it is seen in the studies that there is many types of standard forms of construction contracts in Malaysian construction industry. This can caused confusion and contracting parties familiarize themselves to many forms and hence, not being able to perform their contractual obligations effectively. It is seen here that there may be a need to use one single set of complete and systematic yet flexible to be used in various projects standard form of construction contract for construction industry in Malaysia. This could help to avoid any lack of provision seen in each individual standard form of construction contract.

\section{REFERENCES}

[1] Ashley, D.B. and Workman, B.W. (1986). Incentives in Construction Contracts. The University of Texas at Austin CII.

[2] Clarke, B.G. and O'reilly M. (1999). Civil engineering construction contracts, $2^{\text {nd }}$ ed. England: Thomas Telford.

[3] Collier, K. (2001). Construction Contracts. $3^{\text {rd }}$ ed. New Jersey: Prentice Hall.

[4] Hinze, J. (2001). Construction Contracts. $2^{\text {nd }}$ ed. New York: McGraw-Hill Higher Education.

[5] Nor Jalilah Binti Idris (2006). Effect of Work Programme in extension of Time Entitlement. Thesis Degree, Universiti of Teknologi Malaysia.

[6] Mort, J. (2007, March 19). The Engineering and Construction Contract, 3rd edition Keating Chambers. http://www.keatingchambers.co.uk/resources/seminars/recent/jjm engineeringconstructioncontract.aspx. 8 August 2008

[7] Pilley, J.L. and Coombes, H. (2001). Standard Conditions of Contract. Building Dispute Practitioners' Society Newsletter, Issue 4 - April 2001, 1-9.

[8] Rajoo, S. (1999). The Malaysian Standard Form of Building Contract (The PAM 1998 Form), $2^{\text {nd }}$ ed. Malaysia: Malayan Law Journal.

[9] Robinson, N.M. and Lavers, A.P. (1998). Construction Law in Singapore and Malaysia. Kuala Lumpur: Butterworth.

[10] Thomas, R. (1993). Construction Contract Claims. London: The Macmillan Press Limited.

[11] Williams, K. (1992). Civil Engineering Contracts - Volume 1: The Law, Administration, Safety. England: Ellis Horwood Limited. 